\title{
木質バイオマスのガス化過程における基礎熱分解特性とその予測手法の検討 \\ Investigation of Prediction Method and Fundamental Thermo-decomposition Properties on Gasification of Woody Biomass
}

\author{
森田明宏*
}

Akihiro MORITA

(Received January 7, 2009)

\begin{abstract}
Recently, development of energy transfer technology based on woody biomass remarkably has been forwarding accompanied biomass boom for gasification and liquefaction. To elevate on yield of energy into biomass for transportation and exergy is extremely important for essential utilization and production of bio-fuels.

Because, conversion to bio-fuel must be discussion in detail thermo-decomposition characteristics for biomass main composition formed on cellulose and hemicelluloses, lignin. In this research, we analyze thermo-decomposition characteristics of each biomass main composition on both active (air) and passive (N2) atmosphere. Especially, we suggest predict model of gasification based on change of atomic carbon ratio with thermo-decomposition.

1) Even if it heat-treats cedar chip by $473 \mathrm{~K}$, loss of energy hardly produces it. From this, it acquired that the substance contributed to weight reduction was a low ingredient of energy value.

2) If cedar chip is heated in the $473 \mathrm{~K}$ around, it can be predicted that the substance with a low energy value like water or acetic acid has arisen by thermal decomposition. It suggested that the transportation performance of the biomass improved by choosing and eliminating these.

3) Each ingredient of hydrogen, nitrogen, and oxygen which dissipated in the gasification process acquired that it was direct proportion to the carbonaceous dissipation rate.

4) The action at the time of thermo-decomposition of (the carbon, hydrogen, nitrogen, oxygen which are) the main constituent factors of the biomass suggested a possibility of being predicted by a statistical method.
\end{abstract}

Key Words: Drink waste, Biomass, Fuel, Pyrolysis, Ignition, Combustion, Thermogravimetry, Thermal recycling

\section{1. 緒言}

バイオマスエネルギーの収率を高めることは、バイオマ スを利活用する際に生じるプロセスエネルギーのエクセ ルギーを高める上で重要な課題である。バイオマスエネル ギーの収率は、単位重量当たりと単位体積当たりの指標に よって図られる。なかでも炭化技術は、単位重量当たりの エネルギー収率を極限にまで漸近させ、一方単位体積当た りの向上はペレット化によって達せられている。なかでも、 炭化過程において中間温度で経由するガス化は、その分子 構造あるいは骨格構造の差異により、予測手法を模索して いる段階である。

社会的な面では、バイオマスエネルギーを実用化さらに ビジネス展開が可能な技術開発を行い、社会へ送り出すこ とは急務かつ最重要課題となっている。特に、国内 850 万 $\mathrm{m}^{3} /$ 年、林地に残される森林資源を有効活用することは、
地球環境保全の観点からも大きな意義を持つ。 本研究では、バイオマスの主要 3 成分、セルロース、へ ミセルロース、リグニンの熱分解特性を考察し、そのガス 化過程における組成成分の挙動について検討を行なった。

\section{2. バイオマスの組成成分の熱分解特性}

光合成に起因するバイオマスは、3つの骨格成分を有す る構造体である。それは、セルロース、ヘミセルロース、 リグニンである。これらの3成分は、バイオマスの生育環境、 成長特性により配分比率は異なり、その存在形態も変えて いることが知られている。しかし、大きな括りでは、その 熱分解特性は、周知の通りである。熱分解分析は、示差熱 重量同時測定装置を使用し、重量収率（TG）曲線と吸発熱 （DTA）特性曲線を得た。分析は、活性（空気）雲囲気での 分析と不活性（窒素）雾囲気での分析を行い、その変化か らもその性状を観察した。

*近畿大学理工学部（（０61-1375 北海道恵庭市南島松 157-1）

School of Science and Technology, Kinki University, (157-1 Minami-shimamatu, Eniwa-city, Hokkaido 061-1375 Japan ) 


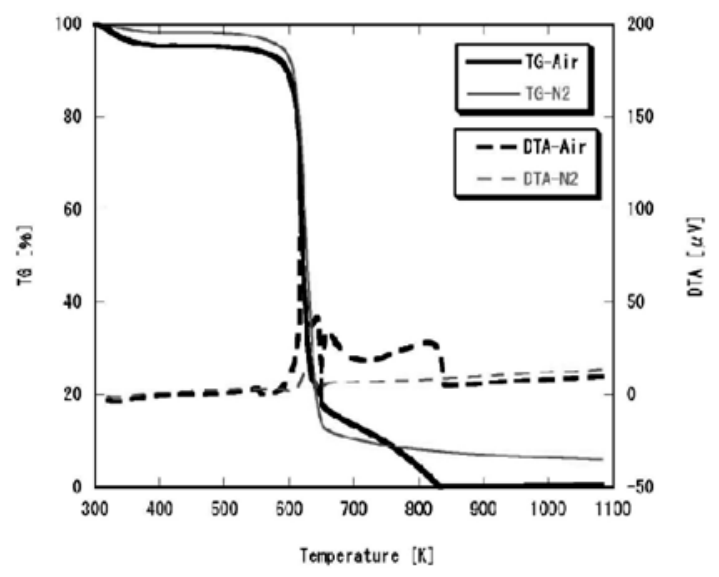

Fig.1 Thermal decomposition of Cellulose.

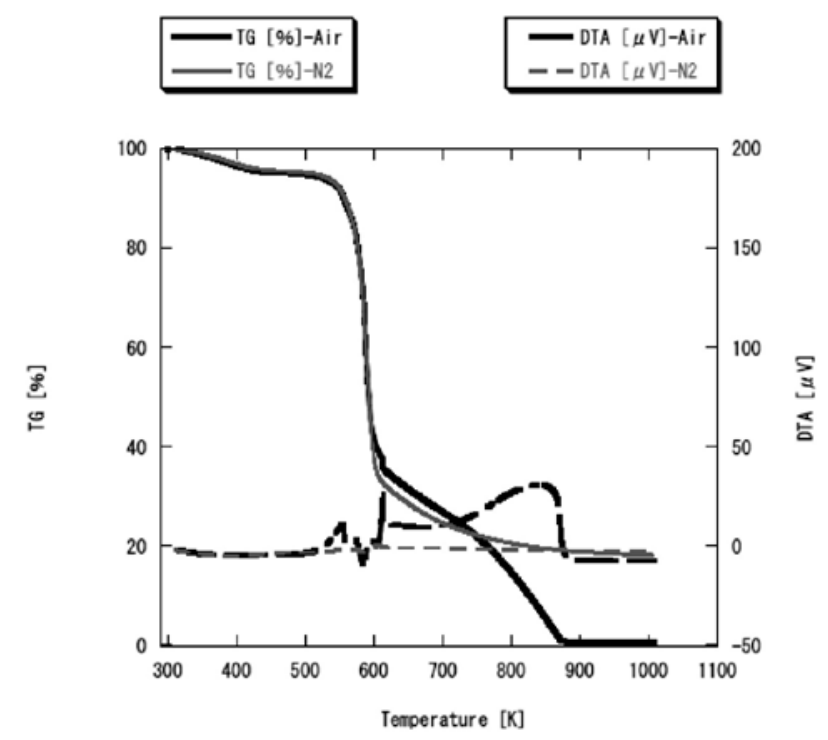

Fig.2 Thermal decomposition of Glucomannan.

セルロースは、重合度 2,000-15,000の鎖状ポリマーから なり、510-670 K 温度帯で分解が生じる。

ヘミセルロースは、重合度 50-200の分岐した構造を有

しており、450-570 K 温度帯で熱分解が生じる。

一方、リグニンは C9 を骨格とする極めて複雑な 3 次元 構造を有しており、550-820 K 温度帯で熱分解が生じる。

ここでは、さらに個々の骨格成分の詳細な熱分解特性を 知ることで、ガス化過程を予測するためのモデリングつい て論じる。

\section{1 セルロースの熱分解特性}

Fig.1 に試薬によるセルロースの示差熱分解特性を示す。 $600 \mathrm{~K}$ で極めて急激なガス化反応が生じていることが分か

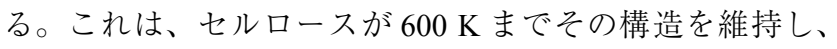
この温度で反応性が極めて高いことを示唆している。 $800 \mathrm{~K}$

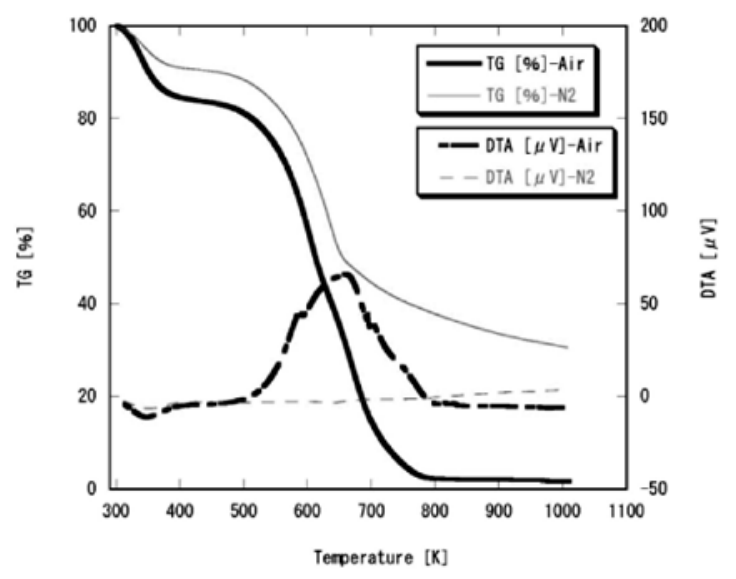

Fig.3 Thermal decomposition of lignin

付近では、チャー燃焼を示す発熱ピークが出現している。

2.2 ヘミセルロースの熱分解特性

Fig.2 は、ヘミセルロースの一種類であるグルコマンナ ンの示差熱分析結果を示す。結果は、セルロースに酷似し ているが $600 \mathrm{~K}$ 付近の発熱ピークが劣り、900 K 付近まで 重量の減少が続いている。これは、残炭率が $20 \%$ を保持 していることから、固定炭素分がガス化しにくい形態で存 在していることを示唆している。セルロースに比して、揮 発成分による発熱特性を示す $600 \mathrm{~K}$ 付近のピークが顕著で ないことは、その分子構造に起因することが予測される。 しかし、チャー化した発熱特性については、セルロース分 子構造との差異が見られないことが分かった。さらに、酸 化（空気）雲囲気と不活性（窒素）雲囲気との熱分解特性 にセルロース、ヘミセルロース共に差異が見られないこと から、ガス化過程での主要因が加熱温度のみであることが 理解できる。

\section{3 リグニンの示差熱分解特性}

Fig.3には、リグニンの示差熱分解特性を示す。セルロー ス、ヘミセルロースに見られる特徽的な 2 つピークは存 在せず、 $700 \mathrm{~K}$ 付近を中心に幅広い温度範囲で山のような発 熱ピークが生じていることが示されている。また、ガス化 過程における重量収率曲線からも緩慢な反応が主であるこ とが分かる。これは、リグニンの複雑な 3 次元構造に起因 していることが洞察される。揮発成分による500 K 付近の ピークが高温側にシフトし、チャー燃焼による $800 \mathrm{~K}$ 付近 のピークが低温側にシフトしていることになる。このこと は、ガス化しにくく、炭化しやすいことに繋がる。しかし、 残炭素収率は $40 \%$ 近くに維持されている。特徵的なのは、 活性（空気）雲囲気と不活性 (窒素) 雲囲気での熱分解特 性が異なることが分かる。その差異は、セルロース、へミ セルロースと比して顕著に現れている。このことは、リグ ニンの熱分解は温度関数のみの影響だけでは、詳細には予 
Table 1 Evaluation of calorific value

\begin{tabular}{|c|c|c|c|}
\hline $\begin{array}{c}\text { Heating } \\
\text { Temperature }\end{array}$ & $\begin{array}{c}\text { Yield of } \\
\text { Weight } \\
\text { K }\end{array}$ & $\begin{array}{c}\text { Calorific } \\
\text { value } \\
\text { MJ/dry-kg }\end{array}$ & $\begin{array}{c}\text { Yield of } \\
\text { evaluation }\end{array}$ \\
\hline 423 & 1 & 21.0 & 100 \\
\hline 473 & 0.99 & 20.9 & 99 \\
\hline 523 & 0.92 & 21.3 & 93 \\
\hline 553 & 0.78 & 22.4 & 83 \\
\hline 573 & 0.64 & 23.6 & 72 \\
\hline 603 & 0.41 & 27.9 & 54 \\
\hline 873 & 0.25 & 33.5 & 40 \\
\hline
\end{tabular}

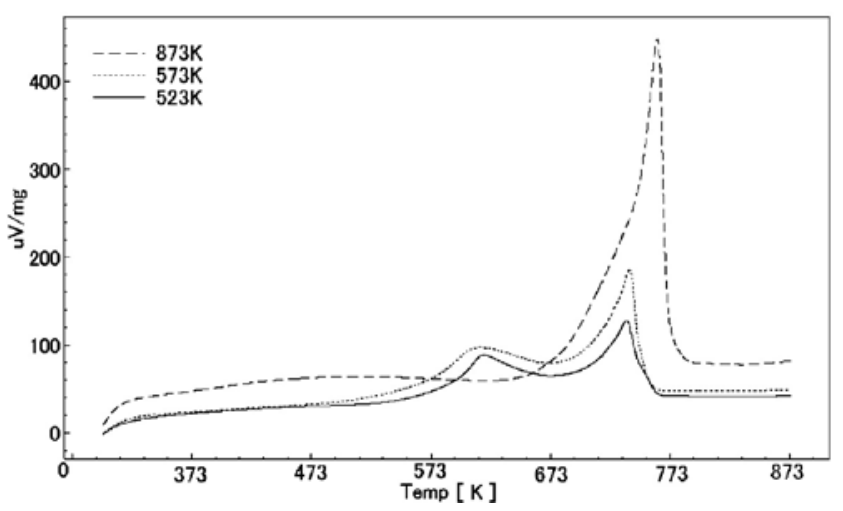

Fig.4 Change of DTA curves for heating temperature

測できないことを示唆している。今後の検討課題である。

\section{3. 熱処理後のエネルギー損失特性}

熱処理温度によるエネルギー損失を解析するために、ま ず、市販されているスギチップを目開き $4 \mathrm{~mm}$ の網ふるい でふるい、約 $40 \mathrm{~g}$ を 16 時間 $378 \mathrm{~K}$ で乾燥した後に重量測 定し、設定温度 $423 \mathrm{~K} 、 473 \mathrm{~K} 、 523 \mathrm{~K} 、 553 \mathrm{~K} 、 573 \mathrm{~K} 、 603$ $\mathrm{K} 、 873 \mathrm{~K}$ で 3 時間加熱したのち重量を測定して、重量収率 を求めた。炭化装置は、ウッドセラミックス研究用製炭装 置（(有)弘前機械開発）を用いた。この装置は加熱炉内を真 空ポンプで減圧（概ね-90 kPa）する方式である。発熱量 は、熱処理後、16 時間 $378 \mathrm{~K}$ で乾燥したのち、ボンべ熱量 計 CA-4PJ (島津製作所)で発熱量を測定した。これにより、 元のチップの持つエネルギーが、熱処理したあとどれだけ 残るか評価できる。この結果は Table 1 のようになり、こ れより $473 \mathrm{~K} て ゙$ 熱処理してもエネルギーの損失は、ほとん ど生じないことが分かる。これは、加熱によりガス化し重 量の減少したものがエネルギー的価值のないものであるた めであり、後述の CHN 分析からの予測で重量の減少が吸 熱反応を示す水分子や酢酸のガスになったためと考えられ る。
Table 2 Results of CHN-analysis

\begin{tabular}{|c|c|c|c|c|}
\hline \multirow{2}{*}{$\begin{array}{c}\text { Heat treatment } \\
\text { temperature }\end{array}$} & \multicolumn{4}{|c|}{ CHN-analysis } \\
\cline { 2 - 5 } & $\mathrm{C}$ & $\mathrm{H}$ & $\mathrm{N}$ & $\mathrm{O}$ \\
\hline 378 & 48 & 6.42 & 0.09 & 44.7 \\
\hline 423 & 49 & 7.05 & 0.49 & 42.8 \\
\hline 473 & 50 & 6.66 & 0.31 & 42.9 \\
\hline 523 & 52 & 6.36 & 0.30 & 41.3 \\
\hline 553 & 55 & 6.00 & 0.28 & 38.7 \\
\hline 573 & 58 & 6.06 & 0.24 & 35.1 \\
\hline 603 & 69 & 4.64 & 0.17 & 26.2 \\
\hline 873 & 87 & 2.35 & 0.21 & 10.2 \\
\hline
\end{tabular}

また、熱処理した試料の示差熱を測定するとFig.4のよ うになり、処理温度が $523 \mathrm{~K}$ 前後の場合、発熱ピークが 2

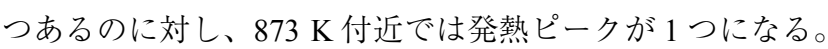
低温側の 1 目のピークは、ガス化を伴う発熱ピークで、 $753 \mathrm{~K}$ 付近の 2 目の発熱ピークは、ガス化後に残った固 定炭素によるチャー燃焼である。DTAの単位は、一般的に $\mu \mathrm{V}$ であるが、Fig.4の縦軸は熱分解前の重量で除法した $\mu \mathrm{V} / \mathrm{mg}$ とした。これによりDTAの最高值が熱処理した温 度と相関がある曲線になり、熱処理温度が高くなると DTA 曲線のピークが高くなる相関が示された。

\section{4. 熱分解による組成成分の散逸}

上述で用いた熱処理した試料を目開き $300 \mu \mathrm{m}$ の網ふる いでふるった後、元素分析装置（株式会社パーキンエルマー 社製 PE2400 シリーズII CHNS/0 アナライザ）により測定 した。酸素の含有率は炭素、水素、窒素の合計より計算で 求めた。また、加熱温度によりガス化した成分の特性を調 べるために、重量収率が 1 になった（加熱の前後で重量変 化のなかった）処理温度 $423 \mathrm{~K}$ を基準にして、各元素の散 逸率 $\Delta \mathrm{Dt}$ を下記の式より求めた。

$$
\Delta \mathrm{Dt}=\mathrm{E} 423-\mathrm{Et} \times \mathrm{Yt}
$$

$\triangle \mathrm{Dt}: \mathrm{t}[\mathrm{K}]$ で熱処理したときの各元素の散逸率 (wt \%) E423: 423[K] で熱処理したときの元素含有率 (wt\%) Et : $\mathrm{t}[\mathrm{K}]$ で熱処理したときの各元素含有率 $(\mathrm{wt} \%)$ $\mathrm{Yt}: \mathrm{t}[\mathrm{K}]$ で熱処理したときの重量収率 (-)

Table 2 の CHN 分析から、炭素の含有率は処理温度が上 がると供に増加しており、特に処理温度 553 〜 603K で急 激に増加している。また、水素の含有率は処理温度が上が るに伴い減っており、特に $603 \mathrm{~K} て ゙$ 急激に減っている。一方、 窒素の含有率は微量 $(0.5 \%$ 以下）で処理温度による変化 が少ない。Fig.5の元素含有率と発熱量の関係から発熱量 は炭素の含有率と比例して増え、水素の含有率が増えると 
木質バイオマスのガス化過程に拄ける基礎熱分解特性とその予測手法の検討（森田）

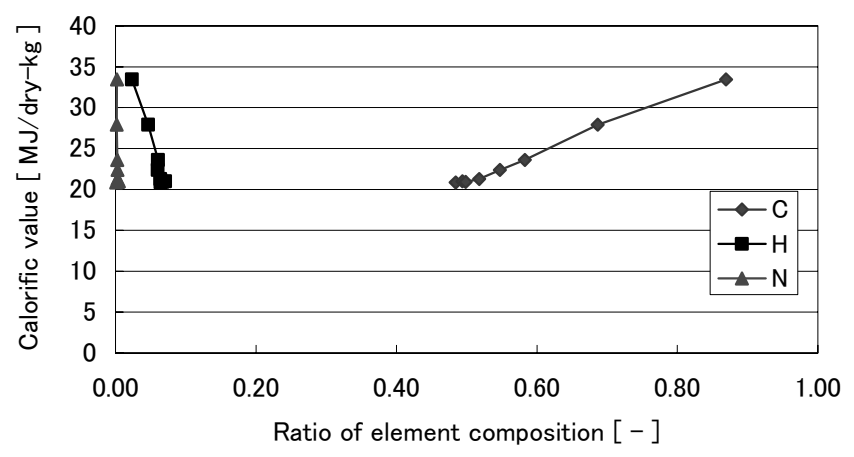

Fig.5 Correlation between each atomic composition ratio and calorific value

Table 3 Dissipation ratio based 423K-treated chip

\begin{tabular}{|c|c|c|c|c|c|}
\hline $\begin{array}{c}\text { Procesiing } \\
\text { temperature(K) }\end{array}$ & $\begin{array}{c}\mathrm{C} \\
(-)\end{array}$ & $\begin{array}{c}\mathrm{H} \\
(-)\end{array}$ & $\begin{array}{c}\mathrm{N} \\
(-)\end{array}$ & $\begin{array}{c}\mathrm{O} \\
(-)\end{array}$ & $\begin{array}{c}\text { Total } \\
(-)\end{array}$ \\
\hline 473 & 0.001 & 0.005 & 0.002 & 0.004 & 0.012 \\
\hline 523 & 0.017 & 0.012 & 0.002 & 0.048 & 0.080 \\
\hline 553 & 0.068 & 0.024 & 0.003 & 0.127 & 0.222 \\
\hline 573 & 0.124 & 0.032 & 0.003 & 0.206 & 0.365 \\
\hline 603 & 0.213 & 0.052 & 0.004 & 0.322 & 0.591 \\
\hline 873 & 0.276 & 0.065 & 0.004 & 0.404 & 0.749 \\
\hline
\end{tabular}

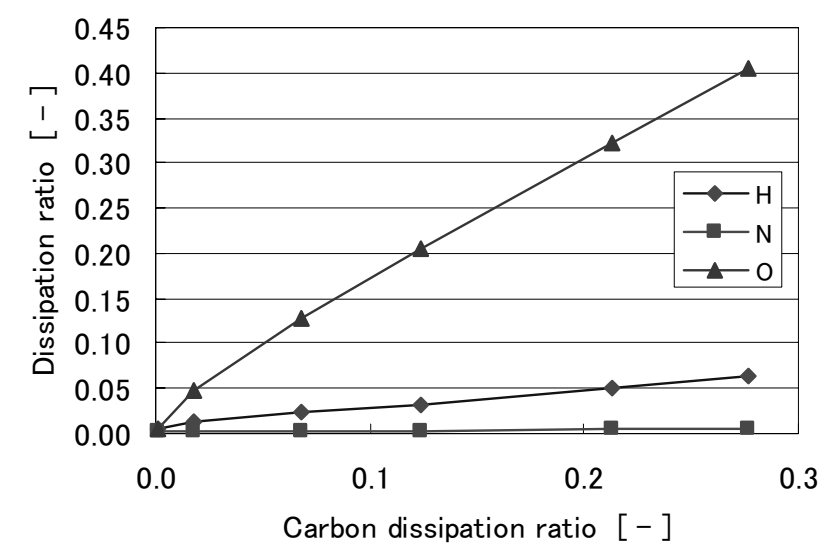

Fig.6 Correlation between atomic carbon dissipation ration and other element dissipation ratio (based on 423K-treated chip)

減る傾向が示されている。

Table 3 は、各散逸元素を (1) 式より求めた結果であり、 更に Fig.6 は炭素散逸率を横軸に取り、他の元素散逸率を 縦軸に相関を示した。これより散逸した炭素と水素は比例 関係であることが分かり、それぞれの散逸率を次のように 求めた。

$$
\begin{aligned}
& \text { 水素の散逸率 } \Delta \mathrm{H}_{\mathrm{t}}=0.234 \times \Delta \mathrm{C}_{\mathrm{t}} \\
& \text { 窒素の散逸率 } \Delta \mathrm{N}_{\mathrm{t}}=0.0158 \times \Delta \mathrm{C}_{\mathrm{t}}
\end{aligned}
$$

Table 4 Dissipation of molar ratio H/O

\begin{tabular}{|c|c|c|}
\hline Heating temp. (K) & $\begin{array}{c}\text { Before deduction } \\
(-)\end{array}$ & $\begin{array}{c}\text { After } \\
\text { deduction } \\
(-)\end{array}$ \\
\hline 473 & 1.13 & 2.12 \\
\hline 523 & 0.25 & 0.27 \\
\hline 553 & 0.19 & 0.20 \\
\hline 573 & 0.16 & 0.17 \\
\hline 603 & 0.16 & 0.17 \\
\hline 873 & 0.16 & 0.17 \\
\hline
\end{tabular}

$$
\text { 酸素の散逸率 } \Delta \mathrm{O}_{\mathrm{t}}=1.46 \times \Delta \mathrm{C}_{\mathrm{t}}
$$

$\triangle \mathrm{C}_{\mathrm{t}}$ : 熱処理温度 $\mathrm{t}[\mathrm{K}]$ における炭素の散逸率 $(\mathrm{wt} \%)$

熱処理の低温側において、木酢液の主要成分である水と 酢酸が発生していると考えられる。これらはモル数で $\mathrm{H} / \mathrm{O}$ = 2 であるが、各熱処理温度で 0.16 ～ 1.13 であった。そこ でCO、NO が木質の熱分解により生じると仮定して、これ らで控除した後モル比で計算したところ、処理温度 $473 \mathrm{~K}$ で $\mathrm{H} / \mathrm{O}=2$ となり、よって、酢酸よりも $\mathrm{CO} 、 \mathrm{NO}$ が生成 されやすいが、この温度付近でのみ水または酢酸のガスが 生成されていることを示唆している（Table 4)。

After deduction $\mathrm{O} / \mathrm{H}=(\mathrm{O}-\mathrm{C}-\mathrm{N}) / \mathrm{H}$

水や酢酸はエネルギーとして利用価值の少ないものであ るので、これらの成分を選択的に排除できるこの温度帯を 活用できるならば、バイオマスのエネルギー収率を改善で きることになる。

\section{5. バイオマスの発熱量の予測}

石炭と比較するために発熱量を、CHN 分析の結果から石 炭の発熱の実験式として知られている Dulong ${ }^{5)} の$ 実験式を 用いて求めた。

$\mathrm{Qdt}=33.8 * \mathrm{C}+144.2 *(\mathrm{H}-\mathrm{O} / 7.94)+9.414 * \mathrm{~S}$

ここで、C、H、O、S は、それぞれ、炭素、水素、酸素、 硫黄の元素分析值である。

Table 5 の実測した発熱量と比較すると、Dulong の実験 式は全体的に実測值より低い熱量を示している。Dulongの 実験式は石炭の発熱量に対する実験式なので灰分を補正す る必要があり、石炭の灰分を $10 \%$ 、スギチップの灰分を $0.5 \%$ と仮定すると、1.1を乗じることにより灰分を補正で き Fig.7のように示され熱量計算の上で、石炭とバイオマ スと区別する必要がないことが分かり、既存の石炭利用技 術に対し、ハンドリングを考慮するだけで利用可能である ことが示された。 
Table 5 Calorific value of actual measurement and calculated values from experimental formula

\begin{tabular}{|c|c|c|}
\hline $\begin{array}{c}\text { Heating } \\
\text { temp.(K) }\end{array}$ & Measurement & Dulong's formula \\
\hline 378 & MJ/dry-kg & MJ/kg \\
\hline 423 & 20.9 & 17.5 \\
\hline 473 & 21.0 & 19.0 \\
\hline 523 & 20.9 & 18.6 \\
\hline 553 & 21.3 & 19.1 \\
\hline 573 & 22.4 & 20.1 \\
\hline 603 & 23.6 & 22.0 \\
\hline 873 & 27.9 & 25.1 \\
\hline
\end{tabular}

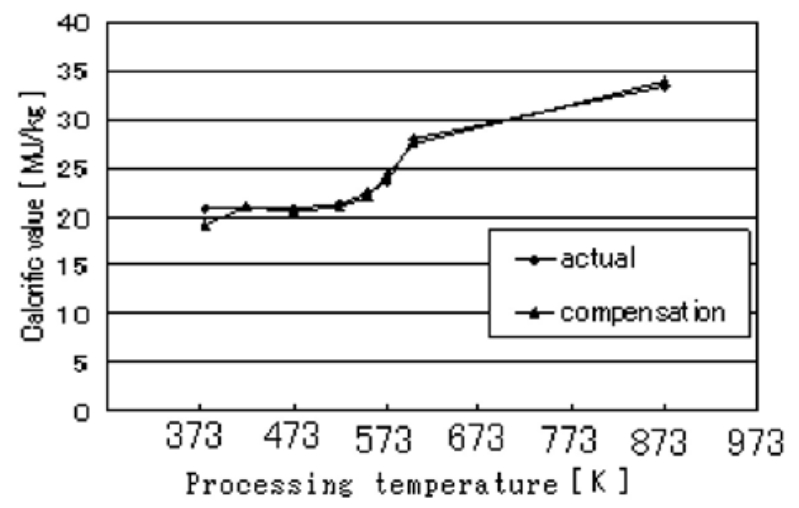

Fig.7 Correlation between processing temperature and calorific value (Comparison calorific value of actual with compensation of Dulong's formula by ash content)

\section{6. 熱分解特性の予測}

バイオマスの構造体であるセルロース、ヘミセルロース、 リグンニンの示差熱分解特性を前述したが、バイオマスは これらが複雑に関係している。そこで化学的処理によりそ れぞれを単離する手法が一般的に使われるが、バイオマス そのものを熱分解した時の各成分の熱分解を観測するのは 非常に困難である。そこで、熱分解による炭素の散逸率が 処理温度との間に規則的な分布を持ち、また、それがシグ モイド曲線に準じて従うと仮定し、他の窒素、水素、酸素 の散逸率は Fig.6で示した炭素の散逸率に比例するとした モデルを作った。

$\mathrm{t}[\mathrm{K}]$ における散逸率を下式のように表し $\mathrm{A} \sim \mathrm{C}$ の各係 数を試行錯誤法で求め、Dは $873 \mathrm{~K}$ 処理における実験值で ある。なお、 $873 \mathrm{~K}$ を境に表面積やミクロポア体積が増減す る ${ }^{6)} こ よ り 、 873 \mathrm{~K}$ 以上では別なモデルを立てるのが適 切であろう。

$$
\Delta(t)=\frac{D}{1+E X P\left\{-\left(\frac{t-B}{A}\right)^{C}\right\}}
$$

Fig.4 で処理温度 $523 \mathrm{~K}$ と $573 \mathrm{~K}$ の示差熱曲線に発熱ピー クが2つある理由として、最初のピークは、処理温度が低 い場合、半炭化物であるチップ内部に易分解性有機物が残 り、その半炭化物を再加熱する場合に、熱分解されること により生じる酸化発熱で、2つ目のピークは炭状になった 物質が表面燃焼しているときの発熱と考えられる。これを 参考に炭素の散逸率は、木の構成物質が熱分解されてガス として散逸するものと（散逸過程 A とする）、木が熱処理 されることにより部分的に生じる乾留物（チャー）が熱分 解されてガスになるもの（散逸過程 B とする）とに分けた。 散逸過程 B で対象になる乾留物には、重油質で揮発し易い タールから揮発しにくい炭状の物質までが含まれることに なる。ここで、散逸過程 B における炭素の散逸率が全炭素 分の $5 \%$ であると仮定すると、実験による $\mathrm{CHN}$ 分析結果 より処理温度 $873 \mathrm{~K}$ での炭素の散逸率が約 $27 \%$ なので散 逸過程 Aにおける炭素の散逸率は $22 \%$ となり、試行錯誤 方法で散逸炭素率の式を下式のように求めた。モデル 1 に

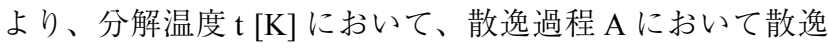
する炭素分 $\triangle \mathrm{Cl}$ ， 及び、散逸過程 $\mathrm{B}$ において散逸する炭 素分 $\triangle \mathrm{C} 1 ”$ は、

$$
\triangle C 1^{\prime}=\frac{0.22}{1+E X P\left\{-\left(\frac{t-300}{40}\right)^{2}\right\}}
$$

$$
\triangle C 1^{\prime \prime}=\frac{0.05}{1+E X P\left(-\frac{\mathrm{t}-400}{40}\right)}
$$

これらの式から次のようなことが推測される。散逸過程 A において散逸する炭素は (8) 式の C1'より、423 K から 徐々に分解が始まり分解ピークは $573 \mathrm{~K} て ゙$ 迎え、それを過 ぎると $723 \mathrm{~K}$ まで徐々に熱分解される量が減少する曲線を 有しており、また、同様に散逸過程 Bにおいては (9) 式の C1”より $473 \mathrm{~K}$ から徐々に分解が始まり分解のピーク温度 は $673 \mathrm{~K}$ で、更に熱処理温度が上がると $873 \mathrm{~K}$ まで徐々に 熱分解される量が減っていく。

(8)、(9) 式から求めた炭素の散逸率を (2)〜 (4) 式に代入 すると水素、窒素、酸素の散逸率が求まる。これらを灰分 修正した Duong の実験式に代入することにより発熱量が 求まる（Fig.8）。これは、実測した発熱量と比較してほぼ 同じである。よって、この結果は、このような統計手法を 用いて熱分解の分解特性を解析できる可能性を示唆してい る。 


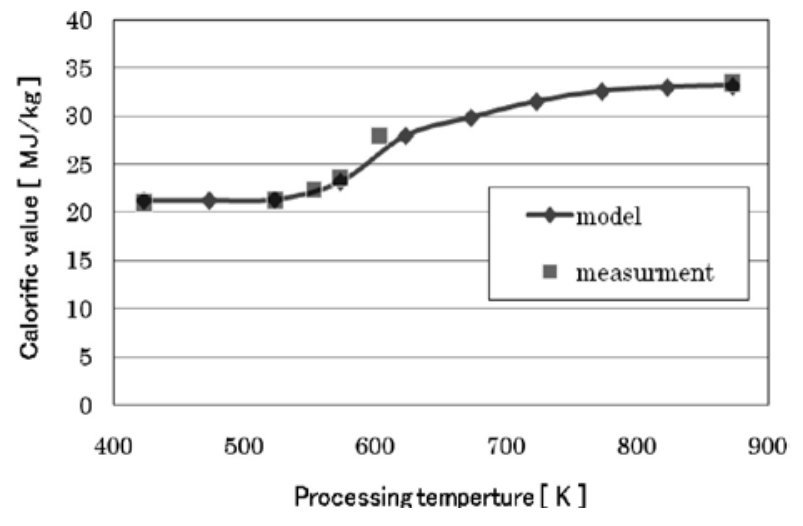

Fig.8 Result of predicted calculation between calorific value and processing temperature

\section{7. まとめ}

本研究では、バイオマスの主要構成要素であるセルロー ス、ヘミセルロース、リグニンの重量収率特性と吸発熱特 性を測定し、それぞれの熱分解特性を考察した。また、加 熱温度を変化させた試料を解析することにより熱分解にお ける組成成分の挙動について分析し、次の知見を示した。

1) スギチップは、 $473 \mathrm{~K}$ で熱処理してもエネルギーの損失 が、ほとんど生じない。これは、重量減少に寄与した物 質がエネルギー的価值の低い成分であることを得た。

2) スギチップを $473 \mathrm{~K}$ 付近で加熱すると熱分解によりエネ ルギー価值の低い水や酢酸が生じていると予測できる。 これらを選択的に排除することによりエネルギー的観点 からバイオマスの輸送性を向上できることを示唆した。
3) ガス化過程で散逸した水素、窒素、酸素の各成分が、炭 素の散逸率と正比例の関係にあることを得た。

4) バイオマスの主な構成要素である炭素、水素、窒素、酸 素の熱分解時の挙動を統計的手法により予測できる可能 性を示唆した。

\section{謝 辞}

本研究の熱分析に関して、ご協力頂いた大阪府立工業高 等専門学校・難波邦彦教授に謝意を表する。また、本研究 の一部は、文部科学省平成 18 年度都市エリア産学官連携促 進事業による宮崎県木材利用技術センター（研究開発代表 者・藤本英人氏）で実施した実験ノートによった、関係者 各位に感謝の意を表する。

\section{参考文献}

1) 本庄孝子、井田民男、渕端学、佐野宽、日工六誌、84, 142148 (2005) : Honjo, T., Ida, T., Fuchihata, M., Sano, 菁 H., J. Jpn. Inst. Energy, Vol. 85, No. 6, 2006

2) 有馬孝菁、木材学会誌、19 (9), 435-442 (1973) : Arima, T., J. Jpn. Wood Research Society, 19 (9), 435-442 (1973)

3）有馬孝菁、木材学会誌、19 (9), 443-450 (1973) : Arima, T., J. Jpn. Wood Research Society, 19 (9), 443-450 (1973)

4) 有馬孝菁、木材学会誌、19 (10), 475-482 (1973)：Arima, T., J. Jpn. Wood Research Society, 19 (10), 475-482 (1973)

5) 社日本エネルギー学会 [編]、バイオマスハンドブック、(オー ム社)、p18 (2002)

6) 森美知子、斉藤幸恵、信田聡、有馬孝菁、木材学会誌、46 (4), 355-362 (2000) : Mori,M., Saito, Y., Shida, S., Arima, T., J.Jpn. Wood Resarch Society, 46 (4), 355-362 (2000) 